\title{
Students' Experience with Flipped Learning Approach in Higher Education
}

\author{
Farah Mohamad Zain*, Siti Nazuar Sailin \\ School of Education and Modern Languages, College of Art and Sciences, Universiti Utara Malaysia, Malaysia
}

Received June 23, 2020; Revised August 6, 2020; Accepted August 25, 2020

\section{Cite This Paper in the following Citation Styles}

(a): [1] Farah Mohamad Zain, Siti Nazuar Sailin, "Students' Experience with Flipped Learning Approach in Higher Education," Universal Journal of Educational Research, Vol. 8, No. 10, pp. 4946 - 4958, 2020. DOI: 10.13189/ujer.2020.081067.

(b): Farah Mohamad Zain, Siti Nazuar Sailin (2020). Students' Experience with Flipped Learning Approach in Higher Education. Universal Journal of Educational Research, 8(10), 4946 - 4958. DOI: 10.13189/ujer.2020.081067.

Copyright $\bigcirc 2020$ by authors, all rights reserved. Authors agree that this article remains permanently open access under the terms of the Creative Commons Attribution License 4.0 International License

\begin{abstract}
This study aims to discover students' experience with flipped learning approach. In particular, this study aims to identify key elements of the flipped learning experience to build flipped learning framework that could be used as a guiding framework for instructional designers. This study employs qualitative research design and is supported by the meaningful learning theory and student engagement model which acts as a theoretical framework. A total of 16 postgraduate students who enrolled in Master of Educational Management programme participated in this study. Data is collected through open ended questionnaire, and reflections by the students and the instructor. The finding reveals elements of students' engagement in the flipped learning approach which consists of (i) fun learning, (ii) active learning, (iii) collaborative learning, and (iv) technology enhanced learning. The findings revealed that students reported positive experiences towards the exposure of the flipped learning approach, which supported the meaningful learning theory and student engagement model. It is envisaged that the results of this study would provide significant impact in the way higher education courses should be delivered. Through flipped learning approach, the focus of the instructional approach is no longer providing direct content to the students, but to allow students to construct the knowledge themselves and be responsible in their own learning.
\end{abstract}

Keywords Flipped Learning, Meaningful Learning, Engagement Model, Fun Learning, Active Learning, Collaborative Learning, Technology Enhanced Learning

\section{Introduction}

The Industrial Revolution 4.0 has changed the world especially in the field of technology with the advent of Internet of Things (IoT), Big Data and Artificial Intelligence. This revolution not only affected the industry but also the educational landscape and eventually the evolution of Education 4.0. Trends in Education 4.0 include project-based learning, accelerate remote learning, data analysis, personalized learning, choice of education tools, changes in exam pattern and assessment, and field-specific experience [1]. As Education 4.0 focusses on the use of technology, it is closely linked to the development of Information and Communication Technology (ICT).

The development of ICT has led to the availability of various resources/contents on the Internet to be shared and used publicly to support, enhance and optimize the delivery of information to students. The use of ICT in education i.e. by integrating technology into the curriculum has a significant impact on student achievement. Students who are exposed to technology through education have better knowledge, presentation skills, are innovative and more competitive compared to other students.

Through the Malaysian Education Development Plan 2013-2025, Malaysia highlighted 11 transformational areas. Among them, Area 7 focused on utilizing ICT to enhance the quality of teaching in Malaysia. Educators should maximize the use of ICT for remote learning and self learning to expand access to high quality teaching regardless of the location or level of student competencies $[2]$. 


\subsection{Theoretical Framework}

The theoretical framework adopted for this study is based on the meaningful learning theory within the constructivism perspectives [3][4]. This theory illustrates that meaningful learning is resulted from the experience and active involvement of students [5], construction of knowledge [6] and it engages complex cognitive structures within the brain [7]. In order for meaningful learning to take place, students need to be involved in the learning process where they will learn through their personal experiences. The role of educators is to facilitate learning and to ensure students are actively engaged in the student centered learning process. Through flipped learning, students are expected to experience learning through digital technologies, engage in discussions, participate in group activities, share experiences and implement self-learning.

There are five elements in the meaningful learning theory that are active, constructive, intentional, authentic, and cooperative [3] [4]. Research in education has shown that students successfully learn through active engagement with the help of technology-based materials and activities [8][9][6]. Flipped learning is an ideal approach to achieving active, constructive, intentional, cooperative and authentic tasks using Web 2.0 tools such as Nearpod, Quizizz and EdPuzzle.

Research also suggests that student engagement allows students not only to focus on students' action, but also develop their feelings and engage with their thoughts. Student engagement essentially requires physical as well as psychological participation [10]. [11] defined student engagement as "the intensity and emotional quality of children's involvement in initiating and carrying out learning activities" (p.572). There are three dimensions of student engagement model, namely behavioural engagement, cognitive engagement and affective engagement [12][13]. The characteristics of each dimension are simplified in Table 1 below.

Table 1. Dimensions of Student Engagement Model (Adapted from [14][12][13])

\begin{tabular}{|c|c|}
\hline Engagement & Component of Engagement \\
\hline $\begin{array}{c}\text { Behavioral Engagement } \\
\text { (Action) }\end{array}$ & Participation, effort, attention, conduct \\
\hline $\begin{array}{c}\text { Cognitive Engagement } \\
\text { (Thought) }\end{array}$ & $\begin{array}{c}\text { Will, skills \& strategies, self-regulation, } \\
\text { deep learning }\end{array}$ \\
\hline $\begin{array}{c}\text { Affective Engagement } \\
\text { (Feeling) }\end{array}$ & $\begin{array}{c}\text { Positive emotion, belonging, social } \\
\text { support, personal growth }\end{array}$ \\
\hline
\end{tabular}

Active participation and overall student engagement in an activity have been identified as key determinants of behavioral engagement [15]. Active participation includes participating in university-sponsored activities, attending lectures and contributing ideas during lectures, completing assigned tasks, and allocating time for additional activities [16]. Students are also more inclined to engage in the teaching and learning process when the activities are challenging, enriching, and are able to extend their abilities
[17]. Studies have demonstrated activities that emphasize high-level thinking skills such as analyzing, synthesizing and assessing attract students to engage actively [18]. In addition, positive emotions are also often associated with student engagement and performance [19]. Enjoyment of learning can improve student engagement by maintaining cognitive resources; focus on learning tasks; promote curiosity and intrinsic motivation; and having positive effects on students' self-regulation [19].

\section{Literature Review}

\subsection{Flipped Learning Approach}

Flipped learning also known as 'reversed teaching', 'blended learning' and 'inverted classroom' and 'flipped classroom' [20][21]. According to [22], flipped learning is an instructional strategy in which direct instruction moves from the group learning space to the individual learning space, turning the resulting group space into an immersive learning environment where the instructor guides students in applying concepts and creatively involving them in the subject matter, while [23] used reversed teaching as a teaching practice that reverses the traditional teaching so that students learn new content at home, and class time is used for "homework," that is, working on problems. Blended learning, on the other hand is a combination of online and face-to-face teaching. Flipped learning is therefore a subset of blended learning [24]. Flipped learning encompasses any use of Internet technology to leverage the learning activities in a classroom, so instructor can spend more time interacting with students [25].

Flipped learning was popularized by [26]. Flipped learning is a pedagogical approach in which teaching and learning that is commonly practiced in lecture halls is reversed or inverted and performed outside of lecture halls [26]. Flipped learning is a teaching strategy that focus on collaborative activities (hands-on) [27]. Short videos are first viewed by students before the class. Meanwhile during the class, the instructor focuses on encouraging $4 \mathrm{C}^{\prime} \mathrm{s}$ activities, namely critical thinking \& problem solving, communication, collaboration and creativity [28] [29]. Post-lecture is focused on reflective writing. Therefore, the main aim of this new learning approach is to prepare students before class [30] and during the course through activities that enhance the quality of face to face [31].

Flipped learning consists of three phases, (1) pre-class (2) in-class (3) post-class. Pre-class are activities that students perform before they enter the classroom. In-class are activities implemented during the class hours to support collaborative learning, constructivism and encourage student-centered learning. Post-class refers to activities after the class hours in which students have to reflect on the learning experience during in class. This activity support reflective learning by encouraging students to develop critical skill based on their learning experiences (figure 1). 


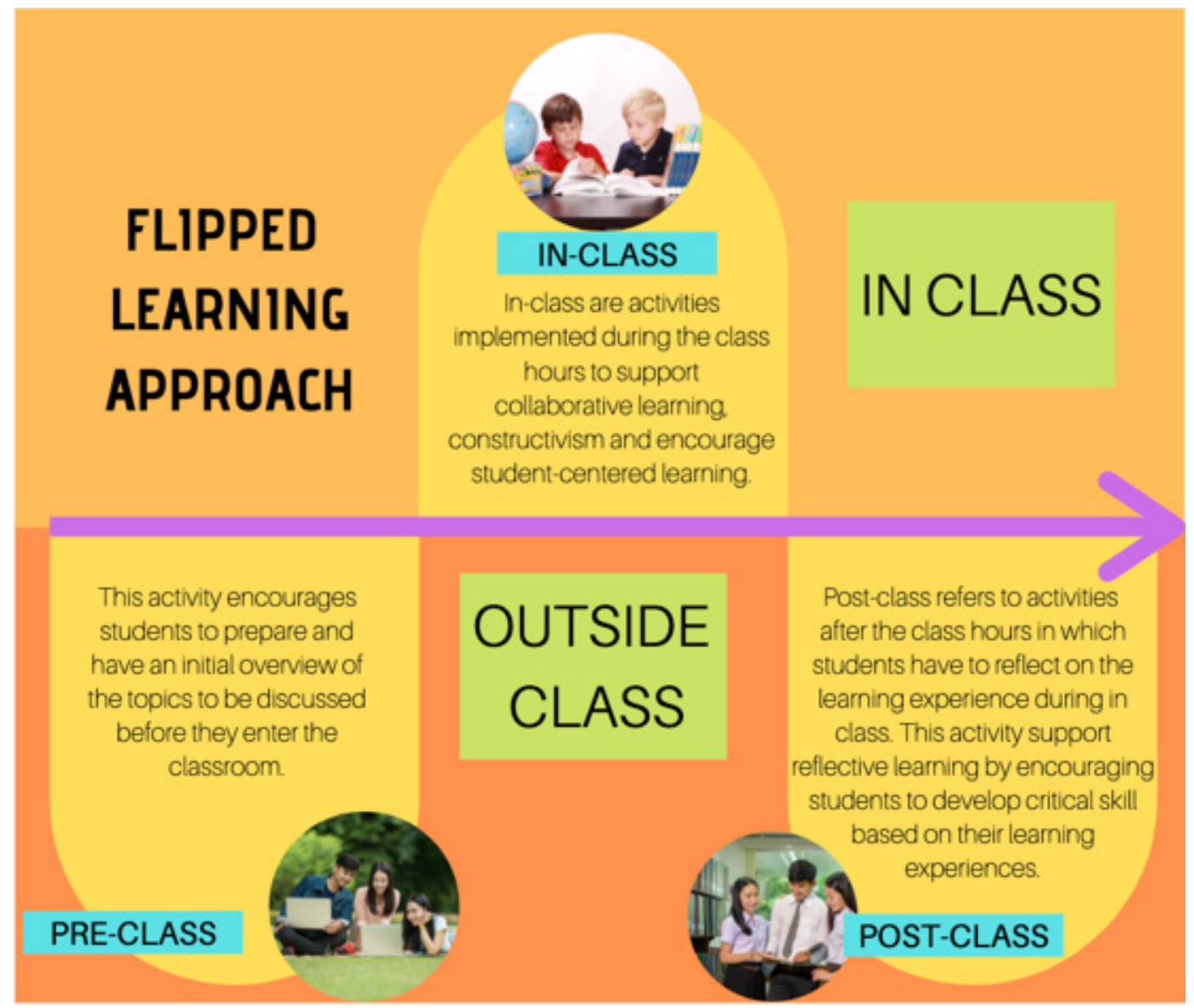

Figure 1. Flipped Learning Approach

The uniqueness of the flipped learning approach is the emphasize on the widespread use of technology. For example, the use of online video is relatively simple to introduce students to the topics that will be learned. In addition, there are several web 2.0 tools available that are able to help instructors to create their own teaching videos. This enables instructors to use their time more effectively in the classroom by engaging students in practical activities in the classroom. It has been proven that student engagement during in class activities lead to better long-term retention [32]. The Horizon reports of higher education highlighted the flipped learning approach as one of the six important developments in Educational Technology for Higher Education in the category of digital strategies [33].

\subsection{Flipped Learning Model}

Researchers have developed a variety of flipped learning models, including flipped mastery models [26], flipped classroom model [34], FLIPPED model [35], Flipped classroom framework [36] and FLIP model [22]. There are also flipped learning models that have been developed based on student-centered learning such as active learning [27], peer-assisted learning [37] and collaborative learning [26]. In addition, Bloom's Taxonomy for cognitive learning is also associated with flipped learning where low-level thinking skills such as memorizing and understanding are achieved at home while high-level thinking skills such as applying, analyzing, evaluating and creating are acquired during lectures [38].

Several studies have studied the components of the models above and are mainly focused on quantitative analysis or merely explaining the features of the flipped learning in general. More investigation is required, especially from the perspectives of students' experience.

\subsection{Traditional Learning}

[39] classifies traditional learning as methods which uses textbooks and teaching through lectures. [40] states that the amenities in the traditional learning is equipped with rows of chairs and desks along with a chalkboard in front of it. According to [41], teaching and learning is traditionally a 'chalk and talk' method or one which uses transparency paper (OHP), while the medium used include printed books. [42] argues that traditional learning lack of the use of technology. The traditional learning approach poses several problems. Among these are lectures that may be ineffective and students are unable to think beyond their knowledge and ability [43]. Additionally, there is lack of interaction between teachers and students, or between 
students with other students. As a result, learning becomes uninteresting, driven by teacher talk, and depends heavily on textbooks. However, the combination of traditional learning and online learning in the teaching and learning process is particularly beneficial to students.

\subsection{Comparison of Flipped Learning and Traditional Learning}

There are various studies which had investigated the effectiveness of the flipped learning approach[44] [45] [46] and most of these studies examined the extent to which this approach impact students learning performance [47]. Analysis of the literature demonstrated mixed results. [48] reported that the flipped learning approach produced better retention than traditional learning approach while proving that students were satisfied with the approach. This is supported by [49] and [45]. In addition, students also acquire higher levels of innovation and collaboration skills than students in traditional settings [26]. The flipped learning approach also aims to increase student engagement during lectures [50].

Previous studies have demonstrated that flipped learning is effective in improving student's retention compared to traditional lectures [51] [52]. According to [53], students prefer and are more likely to favor flipped learning compared to traditional learning. Additionally, students are more prepared when they come to class after watching the video (pre-class) [54]. If the flipped learning is well designed, the interaction between student and instructor will increase [55]. [56] argued that flipped learning can contribute to student engagement, group-based skills, student personal guidance, discussions and creative freedom. [57] believes that flipped learning is effective in helping students learn content and improve self-efficacy when learning independently.

Innovative learning environment and teaching strategies are important factors in enhancing student achievement through learning activities. Therefore, the main goal of the flipped learning is to improve student achievement by focusing on in-class activities that encourage critical thinking rather than focusing solely on lectures in class [58].

Previous studies also found various outcomes related to flipped learning. The majority of studies compared the effectiveness of flipped learning with traditional approach [59] [60] [61]. [61] discovered that student achievement improved after being introduced to flipped learning compared to traditional approach. [62] found no difference in students' academic performance when using both approaches. However, students exposed to the flipped learning are more willing to participate in the classroom and collaborate with other students to enhance their comprehension [63]. This approach also tends to attract students attention for longer periods of time because on average, students are only able to pay attention for only 10 minutes. In addition, through the flipped learning, interactive activities can increase the student's duration of concentration [59].

There are previous studies which show that the flipped learning approach is not effective. For example, [64] reported that students who follow the flipped learning are dissatisfied with the structure of the student-oriented lecture. In addition, too many learning activities provided using the flipped learning contribute to dissatisfaction among students as they lack experience and time constraints [65]. [44] has also found this approach to be ineffective and associated this towards the weakness in content selection (video) [66] [67] and confusion with the unusual approach [63].

In response to the inconsistencies in the previous studies regarding the effectiveness of both approaches, this present study aims to explore students' flipped learning experiences more deeply through qualitative study to get some insights into developing flipped learning framework to guide instructors for more effective integration of flipped learning.

\subsection{Purpose and Rationale of the Study}

In Malaysia, several studies have recently been carried out on the different implementations of the flipped learning in local universities [68][69]. Most of the research has focused on the recommended techniques and educational tools for flipping a classroom and the resulting perceptions of the instructor and students. However, there are limitations in effectively redesigning existing university lectures into flipped learning based solely on meaningful learning theory and their effects. Even though the classes deal with the same learning content, they need to be designed and applied to different types of flipped learning in accordance with the characteristics of subjects, learners, and instructors as well as the teaching approach of the previous class.

This study, therefore, attempts to achieve the following objectives:

1. to explore student experience in using flipped learning approach

2. to identify the essential elements of students' engagement to develop a flipped learning framework

\section{Methodology}

\subsection{Participants of the Study}

The sample of this study consists of Master of Education Management students undertaking the Quality Management in Education course offered during the A181 academic semester of the 2018/2019 session. A total of 16 students enrolled in this course and all were voluntarily involved in this study. Participants were purposely selected 
based on their experience as a teacher as it could contribute towards shaping their understanding of flipped learning approach.

\subsection{Data Collection and Analysis}

Open-ended questionnaire was conducted online through Google Form to obtain meaningful information on students' experiences of the flipped learning approach. The questions provided were unstructured and the respondents were able to answer freely. For example, students were asked on how the flipped learning influence their motivation to learn as compared to traditional approach. Students were also asked to reflect on their participation and engagement in the flipped learning approach as compared to the traditional approach. In addition, data sources utilized for this study consisted of lecturer and students' reflections. The lecturer's reflection focuses on teaching techniques, teaching methods and teaching approaches applied throughout the semester that contribute to improving student knowledge. Gibb's Reflective Cycle Model (1998) was used as a guide in producing critical reflection writing. The data collection was conducted for 12 weeks.

This study employs thematic analysis in analyzing the data. This analysis method is very effective in analyzing patents and themes in any reference source in a specific area of knowledge [70]. The five steps in conducting the thematic analysis are (i) reading the responses obtained and documenting each response systematically, (ii) the researcher repeatedly reads the results of the documentation to ensure that the respondents and the researchers intended meaning is not conflicted, (iii) ratification is conducted on student responses should the researcher find that the documentation is somewhat ambiguous in terms of meaning and understanding, (iv) identify irrelevant data and categorize the data (v) categorized data are segregated by theme, and (vi) evaluate and redefine categorized data.

\subsection{Instructional Design of the Course}

Prior to the study, the researcher (first author) who is also the instructor of the course had come up with the design for the teaching and learning process for both traditional and flipped learning. The instructor utilizes existing lesson plans for traditional learning while for the flipped learning, the instructor redesigned the lesson plans taking into account three major flipped processes, namely pre-class, in-class and post-class. Lesson plans and videos for the flipped learning were peer-reviewed and feedback was provided by other instructors.

Preliminary information on students' knowledge of Web 2.0 tools was collected at the beginning of this study. It shows that most students are familiar with Quizizz, Google Doc, Padlet, Google Form and Powtoon applications. These findings have helped the instructor to plan and design the teaching materials throughout this course. The Web 2.0 tools commonly used by students become a priority for instructors in designing the teaching material and activities.

This study is divided into two phases: the first phase, students are exposed to the flipped learning approach for 6 weeks. Through this approach, the instructor provides short videos developed through Biteable applications and Powtoon aimed at increasing student' interest. The video was uploaded to UUM Online Learning Management System prior to class (pre-class. In-class, the instructor applied Web 2.0 tools to student activities such as Kahoot, Nearpod, Crossword Activity and Quizlet to generate student knowledge. During post-class, students reflected on the relevant topics through Padlet.

In the second phase, the instructor employed traditional learning approach for 6 weeks, wherein the instructor teaches in class based upon lecture-based approach. The content of the lecture is conveyed only through oral presentation with utilizing PowerPoint slides. Through this approach, the dissemination of knowledge takes place is limited to one direction with the instructor as the center of knowledge. In the traditional learning approach, students' activities are limited during in class that include discussion and group presentation. There was no activity given to the student prior to the class.

Table 2 presents the framework of activities throughout the teaching and learning that are divided into two teaching approaches; flipped and traditional learning. In addition, the role of the instructor and student is also shown for each phase during pre-class, in-class and post-class.

Throughout the twelve weeks course, the instructor also utilized WhatsApp Group for communicating with the students and to make announcements of important matters which require immediate actions from students. On the other hand, students use the WhatsApp Group to ask questions or to express problems encountered and to receive quick responses from the instructor.

At the end of the twelve weeks course, students were required to answer open-ended questionnaire and reflections through the Google Form regarding their experiences after they have undergone two teaching approaches; traditional and flipped learning. The instructor also wrote her reflections based on her observations of the student's learning participation and engagement. 
Table 2. Framework of Activities

\begin{tabular}{|c|c|c|c|c|}
\hline \multirow{2}{*}{ Phase } & \multicolumn{2}{|c|}{ Flipped Learning Activities (WEEK 1-WEEK 6) } & \multicolumn{2}{|c|}{$\begin{array}{l}\text { Traditional Learning Activities (WEEK 7-WEEK } \\
\text { 12) }\end{array}$} \\
\hline & Instructor's role & Students' role & Instructor's role & Students' role \\
\hline Pre-class & $\begin{array}{l}\text { - } \quad \text { Create video } \\
\text { - } \quad \text { Share with students }\end{array}$ & 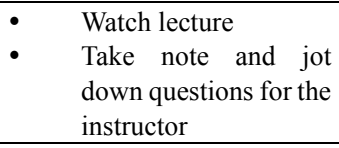 & & \\
\hline In-class & Facilitate discussion & $\begin{array}{ll}\text { - } & \text { Group discussion } \\
\text { - } & \text { Game-based learning } \\
\text { - } & \text { Peer review } \\
\text { - } & \text { Role playing } \\
\end{array}$ & $\begin{array}{l}\text { Instructor directed } \\
\text { instruction }\end{array}$ & $\begin{array}{ll}- & \text { Lecture } \\
- & \text { Presentation }\end{array}$ \\
\hline Post-class & $\begin{array}{l}\text { Check students' } \\
\text { understanding }\end{array}$ & $\begin{array}{c}\text { Students extend their } \\
\text { learning through reflection }\end{array}$ & $\begin{array}{r}\text { Check students' } \\
\text { understanding }\end{array}$ & Do homework \\
\hline
\end{tabular}

\section{Findings and Discussion}

\subsection{Student's Engagement in the Flipped Learning Approach}

This study aims to identify key elements of students' engagement in the flipped learning approach. Analysis of data from students' and instructor's reflective writings indicate that there are four elements of students' engagement in the flipped learning approach; (i) fun learning, (ii) active learning, (iii) collaborative learning and (iv) technology enhanced learning. It has been found that when involved in flipped learning activities, students are more independent and take active roles in the teaching and learning process as discussed below.

\section{(a) Fun Learning}

Students' reflection of their learning experience indicates that fun learning has become one of the important elements that differentiate these two approaches. Most students (S2, S3, S4, S5, S6, S7, S9, S10, S11, S12, S13, $\mathrm{S} 14, \mathrm{~S} 15)$ agree that the flipped learning approach made the teaching and learning activities more engaging, fun and motivating. One student wrote;

"To me, the flipped learning is more interesting and effective for students who are learning while working (part time). This is because students are not bound by the time frame and can choose the appropriate time to view the video or materials provided by the lecturer. In addition, flipped learning is also more interesting and fun for students than traditional approach that sometimes bore students." [S12].

Engagement model defines positive emotional engagement as creating student ties to the institution and influence students' willingness to work [71]. Students who have positive emotions and find learning to be a fun process will naturally participate in the classroom community and learning activities.

Another student, who enrolled as a part-time student in this class also highlighted that flipped learning approach is fun and the activities conducted are able to increase his/her motivation to learn. He/She wrote;
"I really enjoy the activities organized by the instructor. At least my friends and I, being part time students can release tension from work by learning in a cheerful and fun environment. In addition, the flipped learning does not only include activities, but the instructor will teach as usual after the activity has been conducted. It can increase our motivation to learn" [S5].

Even though it was the first time the instructor introduced the flipped learning approach to the students, they found that it is easy for them to adapt to this new learning approach. In addition, they believed that the flipped learning approach is suitable to cater to different student's learning styles. For example, one of the students noted that the flipped learning approach is

"simple and fun. I was able to adapt more easily to the various teaching styles implemented [S10]. He/She further added that "I prefer flipped learning approach over traditional lectures. I would rather participate in hands-on activities than attend lecture-based lectures and discussions only" [S10].

One of the components of meaningful learning theory is the intentional component where students set their learning goals and plan their learning tracks [4]. As the respondents are also teachers, they have begun to reflect on and plan their teaching at school based on the experience they have had throughout the study.

Another student, who is also a teacher, feels that the flipped learning implementation that he has experienced can be a guide for his school.

"Teaching and learning is very effective and can be used as a guide for me to try at school [S5]."

These responses indicate that the flipped learning approach that focuses more on "hands-on activities" rather than "lecture-based approach" is able to capture students" attention and make the teaching and learning more engaging and fun.

\section{(b) Active Learning}

Students in this study also indicate that they have become active learners through the flipped learning 
activities [S2, S4, S5, S6, S7, S8, S10, S11, S13, S14]. The flipped learning approach that is more student-centered as compared to the traditional approach that is more teacher-centered has encouraged students to take active roles in the teaching and learning activities, otherwise they will not benefit from the learning activities. One student wrote;

"I can participate actively in the classroom. This is because, I prefer hands-on activities, (I) prefer exploring and studying materials outside of the classroom through video clips and readings." [S10].

Students are not passive listeners in active learning but play active roles in learning activities; actively manipulating objects and knowledge, and observing results from the learning activities [3].

The flipped learning activities organized by the instructor is able to encourage students to be actively involved even though it may be challenging at first. This active learning not only takes place in the classroom but continues beyond the classroom. The part time students who enrolled in this course benefited most from this approach as they are given ample time to review and study the materials before class at their own pace. One student noted;

"I was more active in teaching and learning when the instructor used the flipped learning approach. This is because the materials provided in advance can help me and other classmates prepare and get an idea of the topics to be learned." [S9].

In addition, another student highlighted that "through the flipped learning, I can be involved not only in the classroom but also during teaching session at home or from long distance. Through this method, my classmates and I were given the freedom to search and study a subject without being bound by just one piece of information. [S8]

Student also indicated that their participation in the teaching and learning activities as "More active and comprehensive as all students participated in the flipped activities, such as participating in Quizlet gamification" (S2). In another view, S2 also highlighted that in the traditional approach, the teaching and learning is more teacher centered or lecture-based and thus lack students-teachers interaction.

These examples of student's responses towards their flipped learning experience indicate that students valued the flipped learning approach which has encouraged active learning participation among them. Students also noted that through flipped learning activities, they are able to study the learning materials and take part in learning activities even before the class has started. This is supported by [72] that argued enabling students to take part in learning activities that encourage self-regulation has shown to have a positive impact on learning outcomes and engagement.

This finding is aligned with the instructor's view, "In terms of learning style, I find that students are more active during flipped than traditional. Students look forward to participating in the planned and implemented activities. Contrary to tradition, where I find students to be more passive and expect information only from the instructor." (Instructor's reflection).

\section{(c) Collaborative learning}

This study also found that the flipped learning approach employed by the instructor encouraged collaborative learning among the students. Students indicated that they are more comfortable with the flipped learning approach as compared to the traditional learning as it encourages two-way interaction among the students and the instructor (S1, S5, S8, S10, S12, S13, S14). Some of the excerpts from the student's responses are as follows;

"The collaboration between me and my friends increased when using the flipped approach because we wanted to get the right answers and help our friends (S1)."

"The flipped learning approach provides an opportunity for us to conduct discussions and interact during and outside of the classroom and provide immediate feedback to the instructor (S10)."

In collaborative learning, students work with peers to solve problem through collaborative activities and discussions to better learn and apply their skills [3]. Unlike traditional approach, flipped learning emphasizes group discussion, problem solving and cooperative learning that requires students to collaborate with their peers to come up with creative and critical ideas.

"Through the flipped learning, we were able to conduct group activities and discussions as well as exchange ideas while solving any given issues/problems. Whereas through the traditional approach, we only listen to instructor and take notes provided by the instructor (S12)."

"When traditional learning is replaced with video recording and other online materials, learning will be more effective through this approach. Students will interact, discuss and solve problems (S14)."

In response to this, the instructor reflected that, "in addition, through flipped, the students communicate and interact better with other students. This is because the activities in the classroom are focused on the student activities rather than solely on the teaching. This indirectly encourages collaboration among students, teamwork and intrapersonal skills." (Instructor's reflection)

Students also highlighted the point that they "cooperate well with team members to complete assigned tasks" (S5), "often share information with friends and instructors" (S8) and feel that "learning is fun because they are able to interact and collaborate with each other" (S13).

These responses indicate that students perceived collaborative learning as an important element in the 
flipped learning approach that help them to improve their intrapersonal and teamwork skills. This confirmed the findings of [56] and [55], that a well-designed flipped learning enable interaction to increase between students and instructors.

\section{(d) Technology enhanced learning}

Analysis of the data also indicated that flipped learning approach enhanced students learning through the use of technology. While some students highlighted technological difficulties such as "slow Internet access, and not understanding the application used" (S7, S9), most of the students felt that the approach is interesting and engaging. S3 wrote; "The flipped learning approach is appropriate with the present environment that requires a more fresh and modern teaching and learning and has visual and ICT aspect" (S3).

Students valued the flipped learning approach as they can study the materials provided in the form of videos or internet materials at their own time and pace. One student wrote, "I can study all the flipped learning videos or materials several times to better understand and be prepared to learn." (S9).

According to [73], effective teaching and learning involve a combination of pedagogical, technological and content knowledge. Therefore, through the flipped learning, students are not only exposed to new learning experiences, but are also exposed to the use of technology in line with learning in the 21 st century that emphasizes digital skills among students.

In addition, the use of interactive and digital materials such as video and Padlet are able to capture student's attention and motivation to learn. This is further noted by S9, "I'm more motivated to learn and is prepared before the instructor began teaching. This is because through the flipped learning approach, the instructor will provide teaching materials in many forms such as a video. Therefore, I can choose an appropriate and convenient time for me to view the video provided. This makes me more motivated to learn. Besides, interesting videos and materials is able to boost my motivation to learn the topic. "

In the instructor's reflection, it was also obvious that students are more engaged in the flipped learning as compared to the traditional approach. "In terms of engagement, I find that students are fully involved in every activity that is conducted through the flipped learning. This is because students are able to participate primarily in technology-assisted activities such as Quizizz and Nearpod. Contrary to traditional learning, I find that students rely only on the instructor to obtain knowledge. Students are not striving to generate their ideas and insights." (Instructor's reflection)

\subsection{Framework of Flipped Learning Engagement}

The above findings on student's engagement in the flipped learning lessons suggest several elements that distinguish between the flipped and traditional learning approach. Based on the findings, the researcher proposed a possible theoretical framework that encapsulates the various learning styles and elements of flipped learning approach to describe student's engagement. Figure 2 illustrates the elements of flipped learning engagement that include fun learning, active learning, collaborative learning, and technology enhanced learning.

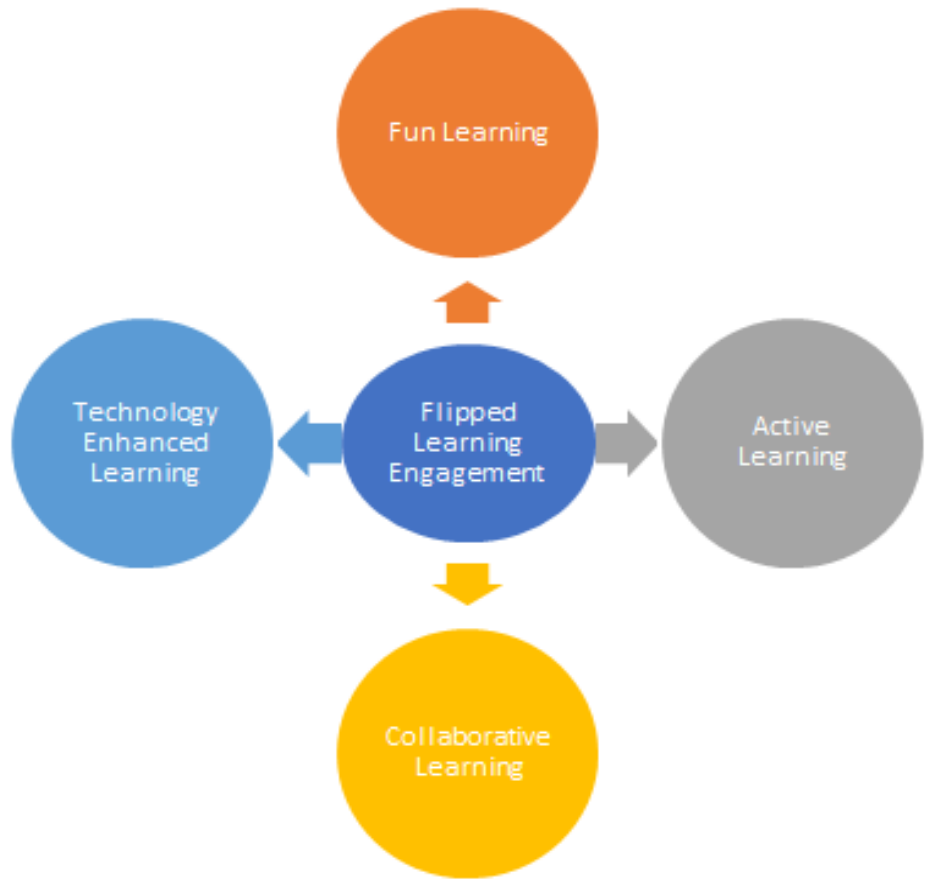

Figure 2. Framework of Flipped Learning Engagement 
The flipped learning engagement framework suggest that students engage in the flipped learning approach through active and collaborative learning supported by the technology enhanced learning activities. At the same time, students enjoy the fun learning environment within the flipped learning approach. There is a consistent body of research that reports improvements in students' engagement as well as their perceptions of the learning experience, and their motivation while utilizing the flipped learning [56][55]. To some extent, the findings on the elements of flipped learning engagement are consistent with the meaningful learning attributes that active learning and collaborative learning will produce meaningful learning.

The framework of flipped learning engagement is aligned with student engagement model. From the analysis, it has been highlighted that students are more engaged in the flipped learning as compared to the traditional approach as they involved in more active and collaborative learning activities, as well as valuing the fun learning environment. To some extent, students' engagement in these activities involved positive emotion (affective engagement), participation (behavioural engagement) and skills and strategies (cognitive engagement) [11, 12, 13, 14, 15]. In addition, the elements of flipped learning engagement found in this study are consistent with the meaningful learning attributes. This study has found two elements that are similar to the active and cooperative attributes [3]. In addition, this study found elements of fun and technology enhanced learning that also contributes to students' meaningful learning experience [6]. Thus, the framework of flipped learning proposed in this study can be used together with the meaningful learning theory and engagement theory for lecturers in higher education in designing flipped learning to ensure students are highly engaged.

Table 3 demonstrates the example of integrating meaningful learning with flipped learning approach and engagement model that can serve as a guide for curriculum designers especially the higher education instructors. Pre-class activities are designed to encourage students' intentional activities that are capable of setting their learning goals. While, in-class activities that are planned should include active, authentic and cooperative learning components in shaping meaningful learning for students. Finally, the post-class activities in the form of reflection can enhance students' constructive experiences. Throughout the flipped learning phases, there are several elements of learning engagement that can be embedded. Some of the elements however may be intertwined and embedded in different flipped learning phases.

Table 3. Integration of Meaningful Learning with Flipped Learning Engagement

\begin{tabular}{|c|c|c|c|}
\hline $\begin{array}{c}\text { Phase in Flipped } \\
\text { Learning Approach }\end{array}$ & $\begin{array}{c}\text { Meaningful Learning } \\
\text { Attributes }\end{array}$ & Flipped Learning Activities & $\begin{array}{c}\text { Elements of learning } \\
\text { engagement }\end{array}$ \\
\hline Pre-class activity & $\begin{array}{c}\text { Intentional } \\
\text { (Goal-directed/regulatory) }\end{array}$ & $\begin{array}{l}\text { Students set their learning goals and plan } \\
\text { their learning track. Students study learning } \\
\text { materials (e.g.: videos) given by the } \\
\text { instructor before the class. }\end{array}$ & $\begin{array}{l}\text { Technology Enhanced } \\
\text { Learning } \\
\text { Cognitive Engagement }\end{array}$ \\
\hline \multirow{3}{*}{ In-class activity } & $\begin{array}{c}\text { Active } \\
\text { (Manipulative/observant) }\end{array}$ & $\begin{array}{l}\text { Students actively involved in a given task } \\
\text { where students should be able to manipulate } \\
\text { the objects and environmental parameters } \\
\text { and observe the results of their } \\
\text { manipulation. }\end{array}$ & \multirow{3}{*}{$\begin{array}{c}\text { Collaborative Learning } \\
\text { Active Learning } \\
\text { Fun Learning } \\
\text { Behavioral Engagement } \\
\text { Cognitive Engagement }\end{array}$} \\
\hline & $\begin{array}{c}\text { Authentic } \\
\text { (Complex/Contextual) }\end{array}$ & $\begin{array}{l}\text { Students involve in real-world learning task, } \\
\text { simulation, problem-based, role play, group } \\
\text { discussion, game-based learning, hands-on } \\
\text { learning activities or other student-centered } \\
\text { learning activities to make learning easier to } \\
\text { remember and easy to understand. }\end{array}$ & \\
\hline & $\begin{array}{c}\text { Cooperative } \\
\text { (Collaborative/conversational) }\end{array}$ & $\begin{array}{l}\text { Students communicate, cooperate and } \\
\text { collaborate to build meaningful knowledge, } \\
\text { learn the skills of other students and } \\
\text { integrate other students' knowledge to solve } \\
\text { problems and perform assigned tasks. }\end{array}$ & \\
\hline Post-class activity & $\begin{array}{c}\text { Constructive } \\
\text { (Articulative/reflective) }\end{array}$ & $\begin{array}{l}\text { Students reflect on what they have learned, } \\
\text { the activities conducted, as well as their } \\
\text { observations throughout the teaching and } \\
\text { learning process. }\end{array}$ & $\begin{array}{l}\text { Technology Enhanced } \\
\text { Learning } \\
\text { Affective Engagement }\end{array}$ \\
\hline
\end{tabular}




\section{Conclusions and Recommendations}

This study aims to explore students' experiences with the traditional versus flipped learning approaches in higher education and to propose a flipped learning framework to help lesson designers. Overall, the experience through the flipped learning approach has made students more active, motivated, independent and responsible for their own learning compared to traditional learning. This is supported by previous studies which affirmed that flipped learning enhances collaboration among students compared to traditional [26] [50], students are more active in flipped learning than traditional [74] [75] [76]. One possible explanation might be the hands-on learning activities, which brought positive experiences that helped them to be active, maintain attention, and ultimately learn more efficiently. In addition, the technology enhanced learning through various use of digital tool and game-based activities throughout the flipped learning phases make the learning processes more engaging and fun.

This study also provided valuable information for educators regarding instructional design and selection of an appropriate tools and learning activities to better facilitate students' engagement in the flipped learning approach. Furthermore, educators can encourage students to sharpen their technology skills along with 21 st century skills.

As this study only found four elements of students' engagement in the flipped learning approach, further study should consider exploring other elements or attributes of meaningful learning and engagement models that might be having significant influence towards students' engagement in a flipped learning approach. In addition, further studies should consider educators acceptance towards implementing flipped learning approach as acceptance of change and innovation is a must and crucial for skill acquisition and survival in education 4.0 [77] such as in the flipped learning approach.

\section{REFERENCES}

[1] Fisk, P. (2017). Education 4.0 the future of learning will be dramatically different, in school and throughout life. Retrieved fromhttp://www.thegeniusworks.com/2017/01/fu ture-education-young-everyone-taught-together

[2] Kementerian Pendidikan Malaysia. (2013). Pelan Pembangunan Pendidikan Malaysia 2013-2025 (Pendidikan Prasekolah hingga Lepasan Menengah). Putrajaya: Kementerian Pelajaran Malaysia.

[3] Jonassen, D.H., Howland, J., Moore, J., \& Marra, R.M. (2003). Learning to Solve Problems with Technology: A Constructivist Perspective (2nd. ed). Columbus, $\mathrm{OH}$ : Merrill/Prentice- Hall.

[4] Howland, J., Jonassen, D.H. \& Marra, R.M. (2012). Meaningful learning with technology. (4th ed.). Columbus, OH: Merrill/ Prentice-Hall.
[5] Hussain, R. M. R., \& Al Saaidi, K. K. (2019). Students as designers of E-book for authentic assessment. Malaysian Journal of Learning and Instruction, 16(1), 23-48.

[6] Sailin, S. N. \& Mahmor, N. A. (2018). Improving Student Teachers' Digital Pedagogy Through Meaningful Learning Activities. Malaysian Journal of Learning and Instruction. 15 (2), 143-173.

[7] Hill, L. H. (2005). Concept Mapping to Encourage Meaningful Student Learning. Adult Learning, 16(3-4), 7-13. doi: $10.1177 / 104515950501600302$

[8] Hamdan, N., P. McKnight, McKnight, K., \& Arfstrom, K. (2013). The flipped learning model: A white paper based on the literature review. The Flipped Learning Network. Retrieved from http://www.flipped learning.org/cms/lib07/ VA01923112/Centricity/Domain/41/WhitePaper_FlippedL earning.pdf

[9] Jimoyiannis, A., Tsiotakis, P., Roussinos, D., \& Siorenta, A. (2013). Preparing teachers to integrate Web 2.0 in school practice: Toward a framework for Pedagogy 2.0. Australasian Journal of Educational Technology, 29(2), 248-267.

[10] Janosz, M. (2012). Outcomes of engagement and engagement as an outcome: Some consensus, divergences, and unanswered questions. In S.L. Christenson, A.L. Reschly \& C. Wylie. (Eds.), Handbook of research on student engagement (pp.695-703). New York: Springer.

[11] Skinner, E. A. \& Belmont, M. J. (1993). Motivation in the classroom: Reciprocal effects of teacher behavior and student engagement across the school year. Journal of Educational Psychology, 85(4), 571-581. Retrieved from http://sfx.unimelb.hosted.exlibrisgroup.com/

[12] Furlong, M. J., Whipple, A. D., St. Jean, G., Simental, J., Soliz, A. \& Punthuna, S. (2003). Multiple contexts of school engagement: Moving toward a unifying framework for educational research and practice. The California School Psychologist, 8, 99-113. Retrieved from www.education.uc sb.edu

[13] Fredricks, J.A., Blumenfeld, P.C. \& Paris, A.H. (2004). School engagement: Potential of the concept, state of the evidence. Review of Educational Research, 74(1), 59-109. doi:128.250.144.144.

[14] Slattery, B (2018). In the groove: A case study into drumming and student engagement. http://hdl.handle.net/11 $343 / 214092$

[15] Skinner, E., Furrer, C., Marchand, G. \& Kindermann, T. (2008). Engagement and disaffection in the classroom: Part of a larger motivational dynamic? Journal of Educational Psychology, 100(4), 765-781. doi:10.1037/a0012840.

[16] Bundick, M. J., Quaglia, R. J., Corso, M. J. \& Haywood, D. E. (2014). Promoting student engagement in the classroom. Teachers College Record, 116(040302). Retrieved from http://www.tcrecord.org.ezp.lib.unimelb.edu.au/content.asp ?contentid $=17402$

[17] Zepke, N. \& Leach, L. (2010). Improving student engagement: Ten proposals for action. Active Learning in Higher Education, 11(3), 167-177. doi:10.1177/146978741 0379680

[18] Coates, H., Hillman, K., Jackson, D., Tan, L., Daws, A., 
Rainsford, D. \& Murphy, M. (2008). Attracting, engaging and retaining: New conversations about learning. Australasian Student Engagement Report (AUSSE). Camberwell: ACER.

[19] Pekrun, R. (2014). Achievement emotions. In M.J. Furlong, R. Gilman \& E.S. Huebner (Eds.), Handbook of positive psychology in schools (pp.146-164). New York: Routledge.

[20] Ash, K. (2012). Educators evaluate "flipped classrooms." Education Week. Retrieved from https://www.edweek.org/e w/articles/2012/08/29/02el-flipped.h32.html

[21] Heyborne and Perrett (2016) Heyborne, W. H., \& Perrett, J. J. (2016). To flip or not to flip? Analysis of a flipped classroom pedagogy in a general biology course. Journal of College Science Teaching, 45(4), 31-37. doi:10.2505/4/jcst16_045 0431

[22] Flipped Learning Network (FLN). (2014). The four pillars of F-L-I-PTM. Retrieved October 1, 2018 from https://flippedlearning.org/definition-of-flipped-learning.

[23] Nguyen, B., Yu, X., Japutra, A., \& Chen, C.-H. S. (2015). Reverse teaching: Exploring student perceptions of "flip teaching. " Active Learning in Higher Education, 17(1), 5161. doi:10.1177/1469787415616727.

[24] Johnson, L., Adams Becker, S., Estrada, V., \& Freeman, A. (2015).NMC Horizon report: 2015 higher education edition. Austin (Texas): The New Media Consortium. Retrieved from http://cdn.nmc.org/media/2015-nmc-horizon-report-H E-EN.pdf

[25] Barseghian T (2011). Three trends that define the future of teaching and learning. Mind/Shift How We Learn. Available at:

http://blogs.kqed.org/mindshift/2011/02/three-trends-that-d efine-the-future-of-teaching-and-learning/ (accessed 10 July 2012).

[26] Bergmann, J., \& Sams, A. (2012). Flip your classroom: Reach every student in every class every day. Alexandria, VA: International Society for Technology in Education.

[27] Lai, C. L., \& Hwang, G. J. (2016). A self-regulated flipped classroom approach to improving students' learning performance in a mathematics course. Computers \& Education, 100, 126-140.https://doi.org/10.1016/j.compedu .2016.05.006.

[28] Kong, S. C. (2014).Developing information literacy and critical thinking skills through domain knowledge learning in digital classroom: An experience of practicing flipped classroom strategy. Computers \& Education, 78, 160-173. https://doi.org/10.1016/j.compedu.2014.05.009

[29] Kong, S. C. (2015). An experience of a three-year study on the development of critical thinking skills in flipped secondary classrooms with pedagogical and technological support. Computers \& Education, 89, 16-31.https://doi.org/ 10.1016/j.compedu.2015.08.017

[30] Bristol, T. (2014). Flipping the Classroom, Teach Learn Nurs 9, 43-46.

[31] Formica, S.P.; Easley, J.L.; Spraker, M.C (2010). Transforming common-sense beliefs into Newtonian thinking through just-in- time teaching. Phys. Educ. Res., 6, $1-7$.
[32] Clark, R. C., \& Mayer, R. E. (2008). Learning by viewing versus learning by doing: Evidence-based guidelines for principled learning environments. Performance Improvement, 47(9), 5-13. https://doi.org/10.1002/pfi.2002

[33] Johnson, L., Adams Becker, S., Cummins, M., Estrada, V., Freeman, A., \& Hall, C. (2016). NMC Horizon report: 2016 higher education edition. Austin (Texas): The New Media Consortium. Retrieved from http://cdn.nmc.org/media/2015 -nmc-horizon-report-HE-EN.pdf

[34] Gerstein, J. (2012). The flipped classroom model: a full picture. User Generated Education, 14, 137-145.

[35] Chen, Y., Wang, Y., Kinshuk, \& Chen, N. S. (2014). Is FLIP enough? Or should we use the FLIPPED model instead? Computers and Education, 79, 16-27.

[36] Kim, M. K., Kim, S. M., Khera, O., \& Getman, J. (2014). The experience of three flipped classrooms in an urban university: An exploration of design principles. The Internet and Higher Education, 22, 37-50.

[37] Nederveld, A., \& Berge, Z. L. (2015). Flipped learning in the workplace. Journal of Workplace Learning, 27(2), 162-172.

[38] Brame, C., (2013). Flipping the classroom. Vanderbilt University Center for Teaching. Retrieved May 19, 2015 from: URL: http://cft.vanderbilt.edu/guides-sub-pages/flipp ing-the-classroom/.

[39] Havice, W.L. (1999). College students' attitudes toward oral lectures and intergrated media presentations. Journal of Technology Studies. XXV (1): 51-56.

[40] Stinson, B.M., \& Claus, K. (2000). The effects of electronic classrooms on learning English composition: A middle ground between traditional instruction and computer based instruction. Technological Horizons in Education. 27(8): 106-107.

[41] Neo, M. \& Rafi, A. (2007). Designing interactive multimedia curricula to enhance teaching and learning in the Malaysian classroom- from teacher-led to student-centered experiences. International Journal of Instructional Media. 34(1): 51-59.

[42] Sloan Consortium (2007). Effective practices. Available: www.sloan-c.org/effective/browse.asp.

[43] Charlton, B. G. (2006). Lectures are such an effective teaching method because they exploit evolved human psychology to improve learning. Medical Hypotheses, 67(6), 1261-1265. https://doi.org/10.1016/j.mehy.2006.08.001.

[44] Szparagowski, R. (2014). The effectiveness of flipped classroom. Honors Projects. Paper 127.

[45] Tally, C.P., \& Scherer, S. (2013). The enhanced flipped classroom: Increasing the academic performance with student-recorded lecturers and practice test in a flipped 'STEM' course. The Journal of Negro Education, 82(3), 339-347.

[46] Vaughan, M. (2014). Flipping the learning: An investigation into the use of the flipped classroom model in introductory teaching course. Education Research and Perspectives, 41, $25-41$.

[47] Raths, D. (2014). Assessing the flipped classroom's impact 
on learning. Teaching and Learning.https://campustechnolo gy.com/articles/2014/01/22/assessing-the-flipped-classroom s-impact-on-learning.aspx.

[48] Minhas, P., Ghosh, A., \& Swanzy, L. (2012). The effects of passive and active learning on student preference and performance in an undergraduate basic science course. Anatomical Science Education, 5(4), 200-207.

[49] Davies, R.S., Dean, D.L., \& Ball, N. (2013). Flipping the classroom and instructional technology intergration on a college-level information system spreadsheet course. Educational Technology Research and Development, 61, 563-580.

[50] Toto, R. \& Nguyen, H. (2009). Flipping the work design in an industrial engineering course. Paper presented at the ASEE/IEEE Frontiers in Education Conference, San Antonio, TX.

[51] Day, J. A., dan Foley, J. D. (2006). Evaluating A Web Lecture Intervention in A Human - Computer Interaction Course. IEEE Transactions on Education. 49(4), 420-431.

[52] Flumerfelt, S., \& Green, G. (2013). Using Lean in the Flipped Classroom for At Risk Students. Education Technology and Society. 16 (1), 356-366.

[53] Lage, M. J., Platt, G. J., Treglia, M., dan Lage, J. (2000). Inverting the Classroom: A Gateway to Creating an Inclusive Learning Environment. The Journal of Economic Education.31(1), 30-43.

[54] DeGrazia, J. L., Falconer, J. L., Nicodemus, G., \& Medlin, W. (2012). Incorporating screencasts into chemical engineering courses. Paper presented at the 119th Annual Conference of the American Society for Engineering Education, San Antonio, TX. Retrieved from http://www.engr.uky.edu/ aseeched/papers/2012/5025.pdf.

[55] Roehl, A., Reddy, S. L., \& Shannon, G. J. (2013). The flipped classroom: An opportunity to engage millennial students through active learning strategies. Journal of Family and Consumer Sciences, 105(2), 44-49.

[56] Millard, E. (2012). 5 reasons flipped classrooms work: Turning lectures into homework to boost student engagement and increase technology-fueled creativity. University Business, December, 26-29. Retrieved from http://www.universitybusiness.com/article/5reasons-flipped-classrooms-work.

[57] Enfield, J. (2013). Looking at the impact of the flipped classroom model of instruction on undergraduate multimedia students at CSUN. Techtrends, 57(6), 14-27.

[58] Huang, Y. M., \& Chiu, P. S. (2015). The effectiveness of the meaningful learning-based evaluation for different achieving students in a ubiquitous learning context. Computers \& Education, 87, 243-253. doi: 10.1016/j.compedu.2015.06.009.

[59] McLaughlin, J. E., Roth, M. T., Glatt, D. M., Gharkholonarehe, N., Davidson, C. A., Griffin, L. M., \& Mumper, R. J. (2014). The flipped classroom: a course redesign to foster learning and engagement in a health professions school. Academic Medicine, 89(2), 236-243.

[60] Pierce, R., Fox, J., \& Dunn, B. J. (2012). Instructional design and Assessment: Vodcasts and active learning exercises in a "flipped classroom" model of a renal pharmacotherapy module. American Journal of Pharmaceutical Education, $76(10), 1-5$.

[61] Wilson, S. G. (2013). The flipped class: A method to address the challenges of an undergraduate statistics course.Teaching of Psychology, 40(3), 193-199.

[62] Findlay-Thompson, S., \& Mombourquette, P. (2014). Evaluation of a flipped classroom in an undergraduate business course. Business Education and Accreditation, 6(1), 63-71.

[63] Strayer, J. (2012). How learning in an inverted classroom influences cooperation, innovation, and task orientation. Learning Environments Research, 15, 171-193. doi:10.1007/s10984-012-9108-4.

[64] Strayer, J. (2007). The effects of the classroom flip on the learning environment: A comparison of learning activity in a traditional classroom and a flip classroom that used an intelligent tutoring system. (Doctoral dissertation).

[65] Butt, A. (2014). Student views on the use of a flipped classroom approach: Evidence from Australia. Business Education and Accreditation, 6(1), 33-44.

[66] Boucher, B., Robertson, E., Wainner, R., \& Sanders, B. (2013). "Flipping" Texas State University's phys- ical therapist musculoskeletal curriculum: Implementation of a hybrid learning model. Journal of Physical Therapy Education, 27(3), 72.

[67] Guerrero, S., Baumgartel, D., \& Zobott, M. (2013). The use of screencasting to transform traditional pedagogy in a preservice mathematics content course. Journal of Computers in Mathematics and Science Teaching, 32(2), 173-193.

[68] Raihanah, M. M. (2014). Flipped classroom \& meaningful learning among UKM graduate students: A teacher's reflection. In Mohamed Amin Embi (Ed.), Blended \& flipped learning: Case studies in Malaysian HEIs. (pp. 255-274). Centre for Teaching \&Learning Technologies, Universiti Kebangsaan Malaysia \& Department of Higher Education, Ministry of Education Malaysia.

[69] Zaid Alsagoff, Baloch, H., \& Norhasliza Hashim. (2014). Flipping large lectures @ IMU. In Mohamed Amin Embi (Ed.), Blended \& flipped learning: Case studies in Malaysian HEIs. (pp. 255-274). Centre for Teaching \& Learning Technologies, Universiti Kebangsaan Malaysia \& Department of Higher Education, Ministry of Education Malaysia.

[70] Braun, V., Clarke, V. (2006). Using thematic analysis in psychology. Qualitative Research in Psychology, 3, 77-101.

[71] Connell, J.P., \& Wellborn, J.G. (1990). Competence, autonomy and relatedness: A motivational analysis of self-system processes. In M.R. Gunnar \& L.A. Sroufe (Eds.), Self processes in development: The Minnesota symposium on child psychology (Vol. 23, pp. 43-77). Hillsdale, NJ: Erlbaum.

[72] Dignath, C., Buettner, G., \& Langfeldt, H.P. (2008). How can primary school students learn self-regulated learning strategies most effectively? Educational Research Review, 3(2), 101-129.

[73] Mishra, P, \& Koehler, M.J. (2006). Technological 
pedagogical content knowledge: A framework for teacher knowledge Teachers College. Record2006108610171054.

[74] Critz, C. M., \& Knight, D. (2013). Using the flipped classroom in graduate nursing education. Nurse Educator, $38(5)$, 210-213. https://doi.org/10.1097/NNE.0b013e3182a0e56a.

[75] Frydenberg, M. (2013). Flipping Excel. Information Systems Education Journal, 11(1), 63.
[76] Lasry, N., Dugdale, M., \& Charles, E. (2014). Just in time to flip your classroom. The Physics Teacher, 52(1), 34-37. https://doi.org/10.1119/1.4849151.

[77] Yusuf, B., Walters, L. M., \& Sailin, S.N. (2020). Restructuring Educational Institutions for Growth in the Fourth Industrial Revolution (4IR): A Systematic Review. International Journal of Emerging Technologies in Learning (iJET). 15(3), 93-109. 